\title{
ANALISIS HUBUNGAN ANTARA STATUS GIZI DENGAN KEJADIAN ANEMIA PADA LANSIA DI UPT. PUSKESMAS COLOMADU 1
}

\author{
Ni'mah hidayatul laili ${ }^{1}$, Vivi nurul laily ${ }^{2}$ \\ ${ }^{1,2}$ Prodi DIII Teknologi bank Darah, Akademi Teknologi Bank Darah Surakarta \\ nimahhidayatullaili@yahoo.com
}

\begin{abstract}
Abstrak
Latar Belakang: Gizi adalah substansi organik yang dibutuhkan organisme untuk pemeliharaan kesehatan. Anemia disebabkan oleh kurangnya zat besi dalam tubuh sehingga kebutuhan zat besi untuk eritropoesis tidak cukup.

Tujuan: Penelitian bertujuan untuk menganalisis hubungan status gizi dengan kejadian anemia pada lansia.

Metode: Penelitian ini adalah deskriptif korelatif dengan pendekatan cross sectional. Populasi penelitian adalah semua lansia usia di atas 60 yang periksa di UPT. Puskesmas Colomadu 1. Metode pengambilan sampel adalah menggunakan accidental sampling. Alat ukur yang digunakan adalah lembar observasi. Metode pengumpulan data berupa data sekunder rekam medis pasien pada bulan September-November tahun 2019. Data dianalisis secara univariat dan bivariat mengunakan uji chi square.

Hasil: Pasien dominan adalah laki-laki sejumlah 71 pasien $(69,6 \%)$ dibandingkan dengan perempuan 31 pasien $(30,4 \%)$. Rerata usia sampel yaitu 69,3 tahun. Status gizi lansia diketahui bahwa sebagian besar termasuk dalam kategori gemuk (82,4\%), sementara hanya 17,6\% pasien yang mempunyai status gizi dalam kategori normal. Status anemia pada pasien lanjut usia yang menderita anemia ( $\mathrm{Hb} 8 \mathrm{~g} / \mathrm{dl}-9,9 \mathrm{~g} / \mathrm{dl}$ ) sejumlah 75 pasien atau 73,5\%, sedangkan yang tidak anemia ( $\mathrm{Hb} 10 \mathrm{~g} / \mathrm{dl}$-batas normal) sejumlah 27 pasien yaitu 26,5\%. Hasil analisis chi square dengan nilai $\mathrm{p}=0,004$. Nilai signifikansi $<0,05$, maka Ho ditolak dan Ha diterima.

Kesimpulan: Ada hubungan antara status gizi dengan kejadian anemia pada lansia di wilayah kerja UPT. Puskesmas Colomadu 1.
\end{abstract}

Kata Kunci: status gizi, anemia, lansia.

\section{Abstract}

Background: Nutrition is an organic substance that organisms need for maintenance of health. Anemia is caused by a lack of iron in the body so that the need for iron for erythropoesis is not enough.

Purpose: Research Objectives was to analyze the relationship between nutritional status and the incidence of anemia in the elderly.

Method: This research is a descriptive analytic study with cross sectional approach health center colomadu 1.The study population was all eldery at 60 th in UPT.Puskesmas Colomadu 1. The sampling method is to use accidental sampling.Measuring instruments in use is the observation. The data obtained in the form of secondary data medical records of patients from September to November 2019. Data are analyzed univariately and bivariately using chi square.

Results: Dominant patients were male, 71 patients (69.6\%) compared to 31 patients (30.4\%). The average age of the sample is 69.3 years. Nutritional status of the elderly is known that most are included in the fat category (82.4\%), while only $17.6 \%$ of patients have nutritional status in the normal category. Anemia status in elderly patients with anemia ( $\mathrm{Hb} 8 \mathrm{~g} / \mathrm{dl}-9,9$ $\mathrm{g} / \mathrm{dl}$ ) was 75 patients or $73.5 \%$, while those without anemia ( $\mathrm{Hb} 10 \mathrm{~g} / \mathrm{dl}$-normal limit) were 27 patients, $26.5 \%$. The results of chi square analysis with $p=0.004$. Significance value $<0.05$, then $\mathrm{Ho}$ is rejected and Ha is accepted. 
Conclusion: There is a relationship between nutritional status and the incidence of anemia in the elderly in the work area of UPT.Puskesmas Colomadu 1.

Keywords: Nutritional Status,Anemia, Elderly

\section{Pendahuluan}

Populasi lansia di Indonesia terus mengalami peningkatan. Data pada tahun 2017 menunjukkan terjadi peningkatan dari 7,6 \% menjadi 8,3\% dari seluruh penduduk Indonesia setara dengan 20,24 juta jiwa (BPS, 2018). Peningkatan populasi lansia merupakan sebuah tantangan untuk pelayanan kesehatan Indonesia karena akan menimbulkan suatu permasalahan baru. Permasalahan tersebut meliputi penyakit degeneratif dan masalah gizi pada lansia yang terus meningkat (Bianchi, 2014).Hal ini disebabkan karena lansia mengalami penurunan aktivitas fisik dan perubahan pola makan yang berdampak pada status gizi (Olivers et.al, 2010). Pada umumnya penyebab yang sering terjadi yaitu lanjut usia kurang efisien dalam menyerap beberapa nutrisi yang dibutuhkan, menurunnya nafsu makan karena penyakit yang dideritanya, kesulitan menelan karena berkurangnya air liur, cara makan yang lambat karena penyakit pada gigi, gigi yang berkurang dan mual. Faktor-faktor tersebut dapat memudahkan populasi lansia untuk terkena masalah gizi, salah satunya adalah anemia.

Pada tahun 2017, prevalensi anemia pada lansia mencapai 34,2 \% (Riskesdas, 2018). Pada lansia penurunan konsentrasi hemoglobin di bawah batas normal merupakan hal yang sering dijumpai dan dapat mengakibatkan permasalahan yang serius. Beberapa penelitian menyatakan anemia pada lansia dapat meningkatkan risiko penurunan kekuatan fisik, penurunan kekuatan otot, meningkatnya keletihan, kelemahan, frekuensi jatuh, meningkatkan risiko untuk dirawat di rumah sakit, menaikkan angka mortalitas dan keterbatasan fungsional serta gangguan kognitif pada lansia. Prevalensi gangguan fungsi kognitif termasuk demensia meningkat lebih dari $25 \%$ terjadi pada kelompok usia 85 tahun keatas (Santos, et.al, 2012). Idealnya, fungsi kognitif yang baik sangat diperlukan agar seseorang dapat meningkatkan kualitas hidup terutama optimalisasi status fungsional, memulihkan produktifititas, kreatifitas dan perasaan bahagianya. Oleh karena itu, penurunan fungsi kognitif sebelum waktunya merupakan masalah serius.

Gizi merupakan salah satu komponen yang sangat penting dalam pembangunan, yang dapat memberikan konstribusi dalam mewujudkan sumberdaya 
manusia yang berkualitas sehingga mampu berperan secara optimal dalam pembangunan.Anemia disebabkan oleh kurangnya zat besi dalam tubuh sehingga kebutuhan besi untuk eritropoesis tidak cukup yang ditandai dengan gambaran sel darah merah yang hipokrom mikrositik, kadar besi serum dan saturasi (jenuh) transferin menurun, akan berperan penting mengikat besi total atau Total Iron Binding Capacity (TIBC) meninggi dan cadangan besi dalam sumsum tulang dan tempat lain sangat kurang atau tidak ada sama sekali (Ella \& Mustafidah, 2010).

Berdasarkan uraian latar belakang masalah di atas, maka peneliti tertarik untuk melakukan penelitian berjudul "Analisis Hubungan antara Status Gizi dengan Kejadian Anemia pada Lansia".

\section{Metode}

Penelitian ini merupakan penelitian deskriptif korelatif dengan pendekatan cross sectional. Penelitian korelasional bertujuan untuk mengetahui korelasi antar variabel. Penelitian ini dilakukan di UPT. Puskesmas Colomadu 1 dari bulan September sampai bulan November 2019. Populasi penelitian adalah semua lansia usia diatas 60 tahun yang periksa pada bulan September hingga November di UPT. Puskesmas Colomadu 1.

Metode pengambilan sampel adalah menggunakan accidental sampling. Alat ukur yang digunakan adalah lembar observasi. Data yang dicari meliputi biodata pasien,keluhan utama dan hasil laboratorium darah lengkap yaitu kadar hemoglobin. Data yang diperoleh berupa data sekunder rekam medis pasien pada bulan SeptemberNovember tahun 2019. Data yang memenuhi kriteria inklusi akan diambil sebagai sampel penelitian. Kriteria inklusi yang digunakan yaitu seluruh pasien dengan batasan usia di atas 60 tahun yang memeriksakan diri di UPT. Puskesmas Colomadu 1 bulan September hingga November 2019. Kriteria eksklusi yang digunakan yaitu data pasien yang tidak tersedia atau tidak lengkap meliputi jenis kelamin, usia, keluhan utama dating ke UPT. Puskesmas Colomadu 1 dan hasil laboratorium darah lengkap. Sampel penelitian dari hasil observasi dalam periode bulan September hingga November 2019 terdapat 102 data rekam medis yang dapat diteliti, data selanjutnya dianalisis secara univariat dan bivariat mengunakan uji chi square. 


\section{Hasil}

Berdasarkan hasil penelitian yang dianalisis secara univariate diperoleh hasil bahwa pasien dominan adalah laki-laki sejumlah 71 pasien $(69,6 \%)$ dibandingkan dengan perempuan 31 pasien (30,4\%). Rerata usia sampel yaitu 69,3 tahun.

Tabel 1. Karakteristik Responden Penelitian

\begin{tabular}{lcc}
\hline \multicolumn{1}{c}{ Karakteristik } & Frekuensi & $\begin{array}{c}\text { Prosentase } \\
(\%)\end{array}$ \\
\hline Jenis Kelamin & & \\
Laki-laki & 71 & 69,6 \\
Perempuan & 31 & 30,4 \\
Umur (Mean \pm SD) & $69,3 \pm 7.1$ & \\
60-70 Tahun & 56 & 54,9 \\
70-80 Tahun & 37 & 36,3 \\
80-90 Tahun & 8 & 7,84 \\
>90 Tahun & 1 & 0,98 \\
Status Gizi /Klasifikasi IMT Lansia & & \\
Normal & 18 & 17,6 \\
Gemuk & 84 & 82,4 \\
Status Anemia / Hemoglobin & & 73,5 \\
Anemia (Hb 8 g/dl-9,9 g/dl) & 75 & 26,5 \\
Tidak Anemia (Hb 10 g/dl-batas normal) & 27 & \\
\hline
\end{tabular}

Status gizi lansia diketahui bahwa sebagian besar termasuk dalam kategori gemuk $(82,4 \%)$, sementara hanya $17,6 \%$ pasien yang mempunyai status gizi dalam kategori normal. Status anemia pada pasien lanjut usia yang anemia sebanyak 75 pasien atau 73,5\%, sedangkan yang tidak anemia sebanyak 27 pasien yaitu $26,5 \%$.

Hubungan antara status gizi dengan kejadian anemia pada lansia di wilayah kerja UPT.Puskesmas Colomadu 1 diperoleh hasil analisis bivariate sebagai berikut:

Tabel 2. Hubungan Status Gizi dan Kejadian Anemia pada Lansia

\begin{tabular}{cccccccc}
\hline \multirow{2}{*}{$\begin{array}{c}\text { Status } \\
\text { Gizi }\end{array}$} & \multicolumn{4}{c}{ Kejadian Anemia } & & \multirow{2}{*}{ Total } & \multirow{2}{*}{ P Value } \\
\cline { 2 - 6 } & \multicolumn{2}{c}{$\begin{array}{c}\text { Tidak } \\
\text { Anemia }\end{array}$} & \multicolumn{2}{c}{ Anemia } & & \\
\cline { 2 - 6 } & $\mathrm{N}$ & $\%$ & $\mathrm{~N}$ & $\%$ & $\mathrm{~N}$ & $\%$ & \\
\hline Normal & 16 & 15,7 & 2 & 2,0 & 18 & 17,6 & \multirow{2}{*}{0,004} \\
Gemuk & 11 & 10,8 & 73 & 71,6 & 84 & 82,4 & \\
Jumlah & 27 & 26,5 & 75 & 73,5 & 102 & 100,0 & \\
\hline
\end{tabular}

\section{Pembahasan}

Tabel 2 didapatkan bahwa hasil analisis chi square dengan nilai $\mathrm{p}=0,004$. Nilai signifikansi <0,05, maka Ho ditolak dan Ha diterima, artinya terdapat hubungan antara 
status gizi dengan kejadian anemia pada lansia di wilayah kerja UPT.Puskesmas Colomadu 1.

Konsumsi makanan berpengaruh dalam kadar hemoglobin. Makanan yang masuk kedalam tubuh akan diproses dan dipecah menjadi zat-zat sesuai yang terkandung dalam makanan tersebut. Makanan yang berpengaruh dalam kadar hemoglobin adalah makanan yang banyak mengandung zat besi. Zat besi yang terkandung dalam makanan akan dimetabolisme tubuh untuk menjadi bahan hemoglobin. Hemoglobin dibentuk dalam sumsum tulang (Muliarini, 2010). Penelitian Lia (2009) memperlihatkan bahwa ada hubungan antara kecukupan sayuran dengan kejadian anemia $(\mathrm{p}=0,000)$ (Meilianingsih, 2004). Ini sama dengan data yang peneliti dapatkan dimana 56,7\% responden kurang mengkonsumsi sayuran. Memang pada penelitian ini tidak memperlihatkan jenis-jenis sayuran apa saja yang dikonsumsi tetapi berdasarkan pengamatan peneliti penduduk lebih banyak mengkonsumsi sayuran hijau. Hal ini didukung oleh penelitian Guntur (2004) yang menyatakan bahwa sayuran dengan kandungan Vitamin $\mathrm{C}$ menghambat pembentukan hemosiderin yang sukar dimobilisasi untuk membebaskan besi bila diperlukan. Absorpsi besi dalam bentuk non heme meningkat empat kali lipat bila ada vitamin C. Dengan demikian resiko anemia defisiensi zat besi bisa dihindari.

Asupan energi pada lansia sangat mempengaruhi pertumbuhaan tubuh, jika asupan tidak kuat dapat menyebabkan seluruh fungsional lansia ikut menderita. Antara lain, derajat metabolisme yang buruk, tingkat efektifitas, tampilan fisik, dan kematangan seksual. Usia lansia merupakan usia dimana terdapat perubahan-perubahan hormonal dimana perubahan struktur fisik dan psikologis mengalami perubahan, diantaranya perubahan sel, sistem persarafan, sistem pendengaran, sistem penglihatan, sistem kardiovaskuler, sistem pengaturan suhu tubuh, sistem respirasi, sistem gastrointestinal, sistem genitourinari, sistem endokrin, sistem muskuloskeletal, disertai juga dengan perubahan psikis berupa ketidakstabilan emosi. Masalah gizi yang utama yang dialami oleh para lansia diantaranya yaitu anemia defisiensi zat besi, kelebihan berat badan/obesitas dan kekurangan zat gizi. Hal ini berkaitan dengan meningkatnya konsumsi makanan olahan yang nilai gizinya kurang, namun memiliki banyak kalori sebagai faktor pemicu obesitas pada usia lansia. Konsumsi jenis-jenis junk food 
merupakan penyebab para lansia rentan sekali kekurangan zat gizi (Istiany \& Rusilanti, 2013).

\section{Kesimpulan}

Berdasarkan hasil penelitian dapat disimpulkan bahwa pasien dominan adalah laki-laki sejumlah 71 pasien $(69,6 \%)$ dibandingkan dengan perempuan 31 pasien (30,4\%). Rerata usia sampel yaitu 69,3 tahun. Status gizi lansia diketahui bahwa sebagian besar termasuk dalam kategori gemuk $(82,4 \%)$, sementara hanya $17,6 \%$ pasien yang mempunyai status gizi dalam kategori normal. Status anemia pada pasien lanjut usia yang anemia sebanyak 75 pasien atau $73,5 \%$, sedangkan yang tidak anemia sebanyak 27 pasien yaitu $26,5 \%$.

Hasil analisis uji chi square dengan nilai $\mathrm{p}=0,004$. Nilai signifikansi $<0,05$, maka Ho ditolak dan Ha diterima,artinya terdapat hubungan antara status gizi dengan kejadian anemia pada lansia di wilayah kerja UPT.Puskesmas Colomadu 1.

\section{Saran}

Bagi responden diharapkan agar lebih aktif mencari informasi kesehatan yang berhubungan dengan status gizi pada lansia dan faktor-faktor penyebab menurunkannya kadar hemoglobin dalam tubuh pada usia lanjut serta faktor-faktor yang dapat mempengaruhi meningkatnya kadar hemoglobin dalam tubuh lansia,sehingga masalah status gizi pada lansia dan penurunan kadar hemoglobin dapat dicegah dengan tepat.

Bagi instansi Puskesmas diharapkan agar Puskesmas dapat memberikan informasi tentang status gizi yang dapat mempengaruhi kejadian anemia pada lansia melalui program Puskesmas seperti penyuluhan, maupun penempelan poster atau penyebaran leaflet agar masyarakat dapat mengetahui dan melaksanakan dalam kehidupan masyarakat sehari-hari sehingga dapat terhindar dari berbagai masalah kesehatan salah satunya anemia .

Bagi peneliti lain agar penelitian ini dapat dijadikan sebagai evidence based dan tambahan informasi dalam upaya untuk mengembangkan penelitian lebih lanjut.

\section{Daftar Putaka}

Adriani, M., \& Wirjatmadi, B. 2012. Perangizi dalam status kehidupan. Jakarta: Kencana Prenada Media Grup. 
BPS. 2018.Statistik Penduduk Lanjut Usia. Jakarta: Badan Pusat Statistik.

Bianchi VE. 2014. Anemia in The Elderly Population. J Hematol. 3(4):95-106.

Ella, F \& Mustafidah, H. 2010.Hubungan antara Status Gizi denganKejadian Anemia pada Remaja Putri.Medika, 15 (1), pp.30-34

Guntur. 2004. Vitamin C Sebagai Faktor Domain Untuk Kadar Hemoglobin Pada Wanita Usia 20-35 Tahun. Jurnal Kedokteran Trisakti. Vol 23, No. 1.

Martina, D. A., \& Kholis, N. F. (Agustus, 2012). Hubungan usia, jenis kelamin dan status nutrisi dengan kejadian anemia pada pasien anemia. Diperoleh tanggal 19 November 2019 dari http://www.ejournalS1.undip.ac.id/index.Php/medico/.../1446.

Olivers M, Hertrampf, Capurro, Wegner D. 2010.Prevalence of anemia in elderly subject living at home: role of micronutrient deficiency and inflammation. P. 834839.

Riskesdas. 2018.Laporan Riset Kesehatan Dasar Tahun 2017 Badan penelitian danPengembangan Kesehatan KementrianKesehatan RI. Jakarta: Badan Penelitian dan PengembanganKesehatan.

Santos IS, Lotufo PA, Menezes PR, Bense IM. 2012. Anemia andDementia Among The Elderly. The Sao Paulo Ageing andHealth Study. 2012; 74-81 